\title{
The evolution of the kinematic analysis to obtain the distance covered by basketball players.
}

\author{
Ana Carolina Panhan', Juliana Landolfi Maia², Lucas Antônio Monezi³ , Milton Shoiti Misuta4, \\ Luciano Allegretti Mercadante ${ }^{5}$.
}

\begin{abstract}
Introduction: The methods used to evaluate the distances covered by basketball players change much over time. With technological and computational advances, now you can perform the tracking of the players in real game situation, without interfering with the performance, or the rules of the sport. Objectives: To conduct a literature review of the findings related to distances covered by male basketball players being in competition situation or not and their methodologies used to obtain the results. Methods: A literature review (GOOGLE SCHOLAR and LILACS) was performed to collect articles about the results of the distances covered by elite basketball players and sub-elite, male, tests or competitions and the methodologies used to obtain these results. Results: According to the literature the methodologies used can be divided in three parts: a) methodologies for subjective direct observation of the games; b) observation from filming; c) Tracking players in image sequences. Four papers were found to direct observation methodology games, four works for observation methodology from filming and five papers for players tracking methodology from filming, totaling 13 projects, 11 articles, a dissertation and a monograph. Conclusion: The methods used have allowed the determination of distances accurately and analysis could differentiate the players and functions in different cases, with several factors involved. The distance covered is very important for physical and technical trainers basketball teams to standardize and periodization of training of athletes and individual or collective, and to improve the performance of the players during the games.
\end{abstract}

Keywords: Basketball kinematic analysis, distances covered, tracking.

\section{INTRODUCTION}

The methods used to evaluate the distances covered by basketball players have suffered major changes over time. At first, the researchers found some limitations due to the lack of validated assessment instruments. With technological and computational advancement, now we can perform tracking of the players in real game situation, without interfering in the performance, or in the rules of the sport, using footage. Records found about the values of distance covered by basketball players are very relevant to coaches and physical trainers, because the periodization of training can be performed in a specific and proper way.

The previous analyzes show results referring to distances covered by players and also for functions performed on the team. Studies found in the literature on distances covered in basketball games can be divided according to the methodology used for the evaluation, such as: a) methodologies for subjective direct observation of the games; b) observation from filming; c) tracking players in image sequences.

Initially, the used methodologies resorted to viewing of the games by an observer who later portrayed the actions that occurred during the matches. The observation of games proved as an indispensable mean for the characterization of the specific requirements that are imposed on players during the competition. In this sense, since the 70s, time-motion analysis (TMA) have been used in basketball, allowing to identify the number and types of movements performed as well as the different technical and tactics actions developed by the players. ${ }^{(1,2,3,4)}$

Researchers in the late 80 's began to use video cameras to record the games and subsequently perform the counting of the steps taken by the players to calculate the distance, still using the average value of the step, which allowed obtaining

Corresponding author: Name: Ana Carolina Panhan Address: Avenida Limeira, 901, Areião, Piracicaba, São Paulo, Brasil. CEP: $13414-903$ Telephone: 33715385 E-mail: carol_panhan@hotmail.com

${ }^{1}$ Doutoranda em Biologia Buco-Dental, Faculdade de Odontologia de Piracicaba, FOP (UNICAMP), Piracicaba, (SP), Brasil.

Full list of author information is available at the end of the article.

Financial support: Coordenação de Aperfeiçoamento de Pessoal de Nível Superior (Capes)

Submission date 11 January 2016; Acceptance date 9 March 2016; Publication online date 6 April 2016 
more precise and accurate values. Some authors performed the analyses dividing players into three functions performed at Court, as follows: shipowners, wings and pivots. They also separated the distances covered by speed, featuring the different intensities of effort. ${ }^{(5,6,7,8)}$

Technologies based on Video analysis have been used to evaluate the performance of athletes in simulated games and especially during competitions; the use of computational software provides more robust and accurate results on the athletes' performance. The tracking of the players from the filming can be performed manually or automatically, in 2D or 3D. The advantage of performing the tracking of players after the filming is that evaluation is performed without interfering with the athletes' performance and the rules of the game..$^{(9,10,11,12,13)}$

However, the aim of this study was to conduct a literature review on the findings related to distances covered by male basketball players in situations of competition or not and their methodologies used to obtain the results.

\section{METHOD}

A review of the literature was conducted to collect articles about the results of the distances covered by elite and sub-elite basketball players, male, in tests or in competitions and the methods used to obtain these results, through the electronic databases LILACS and GOOGLE SCHOLAR, as well as in the literature available on the internet in order to identify the research material in the available and updated bibliographies in English and Portuguese. It was used the following keywords: Basquetebol, distâncias percorridas, rastreamento, análise cinemática, Basketball, distance covered, tracking, and kinematical analysis.

Inclusion criteria involved the works that presented results on the distances covered by basketball players. After a careful review of titles and articles surveyed, were selected those that had the characteristics highlighted keywords studied, were obtained 11 articles, a dissertation and a monograph, properly cited in reference.

\section{RESULTS AND DISCUSSION}

The presentation of the results is divided into three parts, the first part shows the results found in the literature regarding the distance covered based on the direct subjective methodology of games, the second part shows the studies that performed the observation from filming and calculated the distances covered by the players and finally, the third and last part shows the authors who have used specific software and the tracking players in image sequences.

\section{Subjective direct observation of the games}

During the games the observers counted the total number of steps made by the players and then multiplied by an average value of step previously obtained.

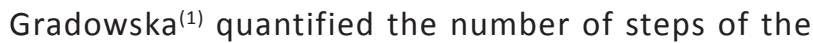
senior men's national team of basketball players from Poland during the European Championship of 1971, through direct observation to discuss the physical performance during the games and the average distance covered per game was 3809.0 meters. This study was the first one found in literature that presents data of distance covered in basketball. Colli and Faina ${ }^{(2)}$ evaluated the distance covered by a player from Portugal team and obtained an average distance of 2292.0 meters per game. Konzag and Frey ${ }^{(3)}$ observed 12 games of the first division of Italian basketball and the results obtained for the average distance covered by the players was 3490.0 meters. Whereas Soares ${ }^{(4)}$ with the same methodology found an average distance covered of 4480.0 meters per game for Russia team.

\section{Observation from filming}

Moreno(5) filmed six of the 24응 $^{(5 p a n i s h ~ L e a g u e ~ g a m e s ~ f o r ~}$ later analysis, obtaining an average value of 5763.0 meters per player. Of this value, 3091 meters were covered in trot and 1577 meters in fast speed. The rest of the distance was covered in recovery pace (828 meters) and maximum effort (267 meters). This study was one of the first studies that used the methodology based on the observation of shooting basketball games. Brandão(6) analyzed three games of school teams in which the average distance covered was 5985.0 meters. Shipowners covered an average distance of 5952.0 meters, wings covered 6029.0 meters and pivots covered 5985.0 meters during a match.

Janeira $^{(7)}$ utilized the video recording for later analysis and determined the distances covered by players through an image of basketball field. To account the distances covered, the author resorted to the use of a scanning table connected to the computer. The author has separated the distances covered by speed range as follows: walk, trot, running and running in maximum effort. The average distance covered per player was 4953.0 meters, being 1838.0 meters walking, 1902.0 meters trotting, 734.0 meters running and 478.0 meters in maximum effort. Brandão et al. ${ }^{(8)}$ analyzed six games at men's senior rank (national team of Portugal) and men's cadet (Centro de Alto Rendimento do Porto - High Performance Center of Porto) obtaining 3738.4 meters of average distance covered by a cadet player and 3037.6 meters by a senior player.

\section{Tracking players in image sequences}

The use of computational software provides more robust and accurate results on the athletes' performance. Now will be presented five papers found in the literature about the tracking of basketball players, their distances covered and the software used to obtain the results.

Erčulj et al. ${ }^{(9)}$ introduced the Sagit measurement system and their aim was to establish the distance covered and average speed of basketball players, using this system. The Sagit 
system was used to track the movements of 23 basketball players from two teams during three games of the National Male Championship Slovenia playoffs. During the 40 minutes of the game active phase the players roamed an average of 4404 meters and during the game passive phase they roamed an additional of 1831 meters. The average speed of the players in active phase of the game was $1.86 \mathrm{~m} / \mathrm{s}$. The differences between the teams in terms of average speed and distance covered were not statistically significant.

Abdelkrim ${ }^{(10)}$ presented the distances covered by 18 non-professional Tunisians basketball players for six games, separated into three functions: shipowners, wings and pivots. The result found to the average of distance covered of the three functions was $7558.0 \pm 575.0 \mathrm{~m}$ by tracking using the PC Teams Sports 4.0 software.

Abdelkrim et al. ${ }^{(11)}$ compared the distances covered between the five positions of players from three basketball teams (under-18, under-20 and senior) and obtained the following results: nine Shipowners (2724 $\pm 711 \mathrm{~m})$, nine Wings-shipowner (1907 $\pm 577 \mathrm{~m})$, nine Wings (2031 $\pm 867 \mathrm{~m})$, nine Wings-pivot $(2067 \pm 837 \mathrm{~m})$ and nine Pivots $(1227 \pm 484 \mathrm{~m})$. The values were estimated from the YO-YO $1 \mathrm{R} 1$ test. The PC Teams Sports 4.0 software was used for the tracking.

Scanlan et al. ${ }^{(12)}$ described the physical differences between professional and non-professional athletes. The matches of the professional players were filmed at a frequency of $25 \mathrm{~Hz}$ and the matches of the amateur players at a frequency of $7.5 \mathrm{~Hz}$. Both recordings were analyzed and the manual tracking was performed at the Labview software (National Instruments, TX, USA). The distances covered by players were calculated for the frontcourt (shipowner and wings) and backcourt (pivots) functions. Professional players of frontcourt roamed

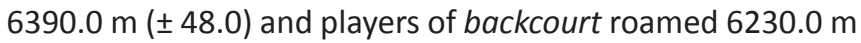
$( \pm 26.0)$. Whereas the sub-elite players of frontcourt roamed

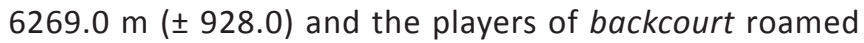
$6034.0 \mathrm{~m}( \pm 321.0)$ in two games, getting a significant difference between the groups.

The activities and stop periods over time of the game provides a useful vision about the fatigue of the players, tactics and strategies of the team and the athletes and team gameplay in sports such as basketball. The players were tracked manually by the Labview software (National Instruments, TX, USA). Therefore, Scanlan et al. ${ }^{(13)}$ quantified and compared the movements of 10 professional players and 12 semi-professional players during one quarter of the game and also during the whole game on four types of motion rating: low intensity (<3 m.s-1), high intensity (>3 m·s-1), change of direction and dribble. Several games were filmed and analyzed through the frequencies and durations of movements, total distances covered and average speeds. Professional and semi-professional players during the first, second, third and fourth periods of play roamed an average of, respectively,
$1653 \pm 38 \mathrm{~m}$ and $1549 \pm 81 \mathrm{~m}, 1591 \pm 24 \mathrm{~m}$ and $1601 \pm 88 \mathrm{~m}$, $1531 \pm 72 \mathrm{~m}$ and $1501 \pm 166 \mathrm{~m}, 1504 \pm 21 \mathrm{~m}$ and $1557 \pm 238 \mathrm{~m}$.

The values of distance covered found are different possibly by several factors. First, the counting of steps during the game without verifiability may not obtain accurate totals; second, each game has its own characteristics regarding the variables that can influence on the distance covered, as total duration, number of changing side of the Court, among others; and finally, the use of software for tracking of players, with manual or automatic.

The kinematic analysis from the videogrammetry uses filming and specific software that does not interfere with the movement of the player or the official rules of the sport. Thus, data acquisition methodologies through computer tracking of the players on the Court are becoming an alternative for the acquisition of information about the events of the game. By tracking and reconstruction processes in real coordinates of the players on the Court, it is possible to get the player's position in a function of time and, consequently, the distances covered, speeds and accelerations.

The technological evolution was of great importance for obtaining results on distance covered of basketball players, not only in testing situations, but mostly on actual games, which can optimize the training and improvement of the team's results. ${ }^{(13)}$ Therefore, the control and analysis of kinematic variables of the players' movements during the games should be the starting point for analyzing the requirements of the sport.

\section{CONCLUSION}

A physical evaluation more direct should include the use of methodologies that perform the analysis of the players' movements. The physiological evidences and motion analysis may suggest that basketball is intermittent; however, there is a large variation in findings about basketball, using the analysis of the players' movements, which is probably due to the different methodologies used.

The technologies related to analysis of athletes' performance have increased due to the interest of researchers in studying different aspects of sports and athletes specifically. The information related to the games, as for example, the distances covered has great importance for coaches and physical trainers of basketball teams for the standardization and periodization of the athletes training, being individual or collective, and for improving the players' performance during the games.

The methods used allow determining accurately these distances covered, and the analyses were able to differentiate players and functions in different cases, with several factors involved. However, it is important to emphasize the computational cost of manual tracking, indicating the need for investment in automatization to basketball, in order to produce reliable information which will allow a significant increase in 
the number of analyzed games that can be available more quickly to technical committees of the teams, as well as the production of new scientific analyses.

\section{AUTHOR'S CONTRIBUTIONS}

${ }^{1}$ ACP: conducted the search for articles, literature review and production of the article. 2- JLM: conducted the search for articles, literature review and production of the article. 3, 4 and 5- LAM, MSM e LAM: They made the correction and formatting of the article.

\section{CONFLICTS OF INTEREST}

The authors declare that they have no conflicts of interest in the research.

\section{AUTHOR DETAILS}

${ }^{2}$ Mestra em Ciências da Nutrição e do Esporte e Metabolismo, Universidade Estadual de Campinas (UNICAMP), Limeira (SP), Brasil.

${ }^{3}$ Mestre em Ciências da Nutrição e do Esporte e Metabolismo, Universidade Estadual de Campinas (UNICAMP), Limeira (SP), Brasil.

${ }^{4}$ Docente, Faculdade de Ciências Aplicadas, Universidade Estadual de Campinas (UNICAMP), Limeira (SP), Brasil.

${ }^{5}$ Docente, Faculdade de Ciências Aplicadas, Universidade Estadual de Campinas (UNICAMP), Limeira (SP), Brasil.

\section{REFERENCES}

1. Gradowska T. L' Activité motrice des jouers de basket-ball de haute compétition pendant un match. Kultura Fiziczna. 1972;2:502-506.

2. Colli R, Faina M. Investigación sobre el rendimiento en el basket. Red: revista de entrenamiento desportivo. 1987;1(2):3-10.

3. Konzag I, Frey O. Radio-telemetrische untersuchingen der herzschlag frequenz von basketballspielern vahrend des wettkampfs. Théorie und praxis des koperkultur. 1987;22(2):213-215.
4. Soares JA. Caracterização do esforço no basquetebol. Revista Horizonte. 1985;9(2):1-12.

5. Moreno JH. Baloncesto: iniciación y entrenamiento. Editorial Paidotribo, Barcelona. 1988

6. Brandão E. Caracterização estrutural dos parâmetros de esforço no jovem basquetebolista. Revista Horizonte. 1992;1(52):135-140.

7. Janeira MA. Funcionalidade e estrutura de exigências em basquetebol. Tese de Doutorado apresentada a Faculdade de Ciências do Desporto e Educação Física - Porto - FCDEF-UP. 1994.

8. Brandão E, Silva JT, Janeira, M. O Lançamento no Basquetebol Português: estudo comparativo do tipo e eficácia do lançamento em função do nível competitivo e da posição dos jogadores no jogo. SJ Ibáñez \& MM Macías, Propuestas para la mejora en el proceso de formación y rendimiento en baloncesto. 2003; Cáceres: Copegraf s/l.

9. Erčulj F, Dežman B, Vučković G, Perš J, Perše $M$, Kristan $M$. An analysis of basketball players'movements in the slovenian basketball league playoffs using the sagit tracking system. Facta Universitatis: Series Physical Education and Sport. University of Niš. 2008;6(1):75-84.

10. Abdelkrim NB, Castagna C, Jabri I, Battikh T, El Fazaa S, El Ati, J. Activity profile and physiological requirements of junior elite basketball players in relation to aerobic-anaerobic fitness. J Strength Cond Res. 2010;24(9):2330-2342.

11. Abdelkrim NB, Chaouachi A, Chamari K, Chtara M, Castagna C. Positional role and competitive-level differences in elite-level men's basketball players. J Strength Cond Res. 2010;24(5):1346-1355.

12. Scanlan AT, Dascombe BJ, Reaburn P. A comparison of the activity demands of elite and sub-elite Australian men's basketball competition. J Sports Sci 2011;(29)11:1153-60.

13. Scanlan AT, Tucker PS, Dascombe BJ, Berkelmans DM, Hiskens MI, Dalbo VJ, HIghway B. Fluctuations in activity demands across game quarters in professional and semiprofessional male basketball. J Strength Cond Res 2015;(29)11:3006:3015. 